\title{
Research on the Rent-seeking Behavior in Equipment Acquisition of PAP
}

\author{
Zhang Jing ${ }^{1}$ \\ Logistics University of PAP, Tianjin, China, 300300 \\ aemail,
}

Keywords: Armed Police Force, Equipment Acquisition, Rent-Seeking, Countermeasure

\begin{abstract}
The rent-seeking behavior is a common phenomenon in the countries which are experiencing economic system transition. There are many kinds of interests and relationship in the equipment acquisition market of Armed Police Force. So the rent-seeking behaviors can inevitably produce. This paper briefly introduces the concept and characteristics of rent-seeking. And establishes a countermeasure model that can explain why equipment acquisition officials of PAP and enterprises can form rent-seeking conspiracy. This paper also puts forward the countermeasures which can restrain the equipment acquisition officials' rent-seeking behaviors. The countermeasures can carry on beneficial exploration in solving the problem of restraining the rent-seeking behaviors in equipment acquisition of PAP.
\end{abstract}

\section{Introduction}

The rent-seeking behavior is a common phenomenon in the countries which are experiencing economic system transition. Especially in the fields of more government intervention, the rent-seeking activities are more common. As a special kind of commodity in PAP, the retrieval process of the weapon and equipment also mingled with multi-stakeholder relations. The various stakeholders' part of the staff all have the characteristics of rational economic man, and they all pursuit self-interest maximization. In China, the supervision legal system equipment acquisition is still not perfect. And the rent-seeking behavior will inevitably produce. Therefore, it is very necessary to further analyze the reason which cause rent-seeking problem in the process of the equipment acquisition in PAP and to discuss how to suppress the equipment acquisition rent-seeking behaviors. In this way, we can promote the healthy development of the equipment acquisition market. And it is of great significance to protect the interests of the Armed Police Forces and our country from being damaged.

\section{The Connotation of Rent-Seeking}

Rent is the remuneration of supplying inelastic production factors. Specific to the Armed Police Force, rent is mainly refers to the part of fund that be paid which are more than the minimum payment in order to obtain the equipment production project which is inelastic supply. For the concept of rent-seeking, Buchanan thought that rent is a waste of social resources which are caused by people's seeking wealth transfer that is relying on government protection. But Tollison considered that rent-seeking is a cost of scarce resources which are used to get artificially created income transfers. Though the above two definitions are not the same, but there are two common characteristics: Firstly, the rent-seeking is an unproductive behavior, the final result of all the rent-seeking activities is the waste of social resources; The second, every rent-seeking activity is associated with monopoly and government regulation, rent-seeking is done by human intervention. 


\section{The Countermeasure Model of Restraining Rent-Seeking Conspiracy}

As a kind of rational "economic man", procurement officers are not always aimed at maximizing social welfare, and they also have motivation to pursue personal utility maximization. Besides, the executives and regulators of the Armed Police Force equipment acquisition work are concentrated in one department. To some extent, this also reduces the degree of effective supervision and increases the acquisition officials' likelihood of opportunism behavior. Therefore, the key to promoting the health running of equipment acquisition work is to control the thought and behavior of the equipment acquisition personnel and officers. This paper focuses on the equipment acquisition officials rent-seeking utility analysis and establishes equipment acquisition official decision model.

Assumptions: Equipment acquisition officers are perfectly rational risk aversion people, and their utility function meet the conditionu' (s) $>0$ and $\mathrm{u}$ " (s) $<0$.

"u” refers to equipment acquisition officials' utility function here;

"s" refers to the amount of the assets that can be monetized;

" $\mathrm{A}_{0}$ " refers to equipment acquisition officials' initial assets;

" $I_{11}$ " and " $I_{22}$ " respectively represent the equipment acquisition officials' annual salary during their working time and the annual pension they can get when they retire if they don't have rent-seeking behavior.

"Q” refers to the spiritual satisfaction (social status or reputation) that the equipment acquisition officials can get that are based on their individual achievement needs if they don't have rent-seeking behavior.

The letter "a" refers to the present value discount coefficient of " $\mathrm{Q}$ ";

The letter " $n$ " refers to the equipment acquisition officials' working years from now until their retirement;

The letter " $m$ ” refers to the equipment acquisition officials' age limit from their retirement to their death;

"(P/A, I, n)"refers to the present value coefficient salary of the equipment acquisition officials' annual salary;

"(P/F, I, n)" refers to the cash value or discount coefficient; "P” here stands for the present-value of money, "A" stands for annuity, "F" stands for the new monetary value if the money's present value began to compute interest from now until some future point, the letter "i" stands for annual interest and " $n$ " stands for age limit.

Assumption: Whether equipment acquisition officials have rent-seeking behavior, their working life and longevity are the same. In this way the equipment acquisition officials will make decisions in two kinds of behavior choice:

The utility value that the equipment acquisition officials will get if they refused to rent-seeking

If a equipment acquisition official doesn't rent, he will have a fixed income " $\mathrm{I}_{11}$ " every year. For the convenience of discussion, we can suppose that all of the equipment acquisition official's annual income used to his consumer spending of this year, and he can have a stable social welfare safeguard after his retirement, and it can ensure that he can get annual pension " $\mathrm{I}_{22}$ " every year. In this way, the present value utility of the equipment acquisition official is as follows:

$$
\mathrm{U}_{\mathrm{l}}=\mathrm{u}\left[\mathrm{A}_{0}+\mathrm{I}_{11}(\mathrm{P} / \mathrm{A}, \mathrm{i}, \mathrm{n})+\mathrm{I}_{12}(\mathrm{P} / \mathrm{A}, \mathrm{i}, \mathrm{m})(\mathrm{P} / \mathrm{F}, \mathrm{i}, \mathrm{n})\right]+\mathrm{aQ}
$$

Here, "I $I_{11}(\mathrm{P} / \mathrm{A}, \mathrm{I}, \mathrm{n})$ " stands for the equipment acquisition official's present value of earning during his working time, " $\mathrm{I}_{12}(\mathrm{P} / \mathrm{A}, \mathrm{I}, \mathrm{m})(\mathrm{P} / \mathrm{F}, \mathrm{I}, \mathrm{n})$ ” stands for his present value of earning after his after his retirement, "aQ" stands for his expected utility value for his future achievement.

The utility value that the equipment acquisition officials will get if they choose rent-seeking

Assumption: The equipment acquisition official's rent-seeking earnings is "W", and the 
possibility of getting caught is p1; If his rent-seeking behavior is found, he will not only get property penalty " $k B$ ", but also get the personal freedom penalty of " $n_{1}$ " years. Among them, the value of " $\mathrm{k}$ " and " $\mathrm{n}_{1}$ " are related to the value of the equipment acquisition official's rent-seeking benefits; The possibility of the equipment acquisition official finding a job after his personal freedom penalty is " $\mathrm{p}_{2}$ ". Suppose his annual income is " $\mathrm{I}_{22}$ " from he find a work until he began to retire; If he can't find a job, his annual social security payments is " $\mathrm{I}_{23}$ " until he die.

Based on the above hypothesis, when the equipment acquisition official does have rent-seeking behavior and his behavior has not been found, his income present value is:

$$
\mathrm{R}_{1}=\mathrm{A}_{0}+\mathrm{W}+\mathrm{I}_{11}(\mathrm{P} / \mathrm{A}, \mathrm{i}, \mathrm{n})+\mathrm{I}_{12}(\mathrm{P} / \mathrm{A}, \mathrm{i}, \mathrm{m})(\mathrm{P} / \mathrm{F}, \mathrm{i}, \mathrm{n})
$$

If the equipment acquisition official's rent-seeking behavior has been discovered, the income present value after the execution of property penalty is:

$$
\mathrm{R}_{2}=\mathrm{A}_{0}-\mathrm{kB}
$$

After the equipment acquisition official perform the personal freedom penalty, his income present value from finding a job until retirement is:

$$
\mathrm{R}_{3}=\mathrm{I}_{21}\left(\mathrm{P} / \mathrm{A}, \mathrm{i}, \mathrm{n}-\mathrm{n}_{1}\right) \cdot\left(\mathrm{P} / \mathrm{F}, \mathrm{i}, \mathrm{n}_{1}\right)
$$

If the equipment acquisition official can't find work after performing the personal freedom penalty, from the time when the personal freedom penalty is end until his death, his income present value is:

$$
\mathrm{R}_{4}=\mathrm{I}_{23}\left(\mathrm{P} / \mathrm{A}, \mathrm{i}, \mathrm{n}+\mathrm{m}-\mathrm{n}_{1}\right) \cdot\left(\mathrm{P} / \mathrm{F}, \mathrm{i}, \mathrm{n}_{1}\right)
$$

If the equipment acquisition official find a job after performing the personal freedom penalty, from the time when he retire until he die, his income present value is:

$$
\mathrm{R}_{5}=\mathrm{I}_{22}(\mathrm{P} / \mathrm{A}, \mathrm{i}, \mathrm{m}) \cdot\left(\mathrm{P} / \mathrm{F}, \mathrm{i}, \mathrm{n}_{1}\right)
$$

Through the formulas (2) (3) (4) (5) (6), we can know that the present value utility of the equipment acquisition official's rent-seeking behavior is:

$$
\mathrm{U}_{2}=\mathrm{u}\left\{\mathrm{R}_{\mathrm{l}}\left(1-\mathrm{p}_{1}\right)+\left[\mathrm{R}_{2}+\left(\mathrm{R}_{3}+\mathrm{R}_{5}\right) \mathrm{p}_{2}+\mathrm{R}_{4}\left(\mathrm{l}-\mathrm{p}_{2}\right)\right] \mathrm{p}_{1}\right\}
$$

Based on the above analysis, we can conclude that whether the rational equipment acquisition official will choose rent-seeking or not all depends on whether the utility of rent-seeking is greater than it of refusing rent-seeking. If $U_{1}>U_{2}$, equipment acquisition officials will refuse to rent; If $\mathrm{U}_{1}=\mathrm{U}_{2}$, because the rent-seeking behavior cannot bring the greater utility, at this time, the equipment acquisition official is unlikely to choose rent-seeking.

\section{Countermeasures to Prevent Equipment Acquisition Officials’ Rent-Seeking Behaviors}

Perfect the Incentive Measures for Equipment Acquisition Officers' Honest Purchase. First of all, the talent selection mechanism should be established and perfected, namely increasing the present value of the equipment acquisition officials' expected achievements for the future. At present, because the procurement organization of PAP is "pyramid" structure, so many procurement personnel have little chance for promotion and they always have the bad thought: no promotion, so seeking more money. And this thought can easily lead to rent-seeking behaviors. Therefore, the equipment acquisition staff who have both political integrity and professional competence should be provided more opportunity to display their talent. It will incentive procurement staff positively and make them have confidence in their prospect and their future achievement expectations. In this way, the rent-seeking behavior will be reduced based on the expected utility of future.

Second, the equipment acquisition officials' salary should be appropriately improved. At present the wages of equipment procurement officials in PAP are still low. In this case, the procurement staff may expand their own utility so the possibility of rent-seeking conspiracy must grow. 
Therefore, improve procurement personnel's wage and welfare benefits, thus the motivation and desire of rent-seeking can be reduced. It also plays a critical role in preventing the equipment suppliers' rent-seeking behaviors.

\section{Establish the Rent Dissipation Mechanism of Armed Police Forces Equipment Acquisition}

Market. In order to eliminate enterprises' rent-seeking behaviors, the rent dissipation mechanism of armed police forces equipment acquisition market must be established. On the one hand, we should appropriately narrow the scope of the government regulations to equipment production through the reasonable control of the border. And the scope of equipment acquisition market's rents should be minimized. On the other hand, based on the modern market economy system, the corporate's bidding process should be opened into public through establishing an open and fair competition mechanism of equipment procurement. And the produced rents which is based on the monopoly of equipment production market should be canceled.

As for China, in order to eliminate the monopoly of equipment production market, the government's current primary task is to foster the competition subject of equipment production market and to introduce more civilian industrial enterprises involved in the construction of weapons and equipment. The establishment and perfection of the competition mechanism will make the equipment in the procurement market rents gradually decrease and eventually disappear, that is to realize rent dissipation, make the enterprise engage in productive profit-seeking for no rent to be found.

Establish Strict Prior-Supervision and Afterwards Punishment Mechanism. First of all, prior-supervision mechanism should be established. On the one hand, in order to monitor and prevent the non-public utilization of public power, the transparency of public power operation process must be improved. This includes formulating clear rules and regulations of Armed Police Forces equipment acquisition fund allocation, releasing the institutions which have distribution rights and the allocation basis in public, etc. On the other hand, we should improve the supervision of institutions (legislation, administration, audit) and strengthen social (universal report, news, public opinion) supervision. That includes supervising the public power of Armed Police Forces equipment acquisition through a variety of organizations; establishing a reporting system and introducing democratic supervision mechanism; military press law and relevant laws should be issued as soon as possible in order to give full play to the role of news media.

Second, establish strict "punishment mechanism". We can start from the following several aspects: Legislation shall be given to severely punish rent-seeking activities; party discipline sanctions, administrative punishment, criminal punishment and economic punishment should be used together and this four measures can't be replaced each other in order to resist the occurrence of rent-seeking behavior; the equipment acquisition personnel will be strictly punished if they choose rent-seeking but the rent-seeking supplier may receive leniency in accordance with the law, so the fate community of the two game sides will be broken and the game board can become imbalance, in this way, one side is easy to be prosecuted, the risk and cost of the other side will increase and the collusion can’t be formed easily.

\section{References}

[1] Lofgren, Mike. Operation Rent Seeking[J]. The Washington Monthly,2015,473-5:

[2] Johan N. M. Lagerlöf. A theory of rent seeking with informational foundations[J]. Economics of Governance,2007,83:

[3] John R. Boatright. Rent Seeking in a Market with Morality: Solving a Puzzle About Corporate Social Responsibility[J]. Journal of Business Ethics,2010,884:.

[4] Robert D. Tollison. The economic theory of rent seeking[J]. Public Choice,2012,1521:. 
[5] OUDOT, JEAN-MICHEL. Performance and Risks in the Defense Procurement Sector[J]. Journal of Public Policy,2010,302:.

[6] Sunwoong Kim, Yoon-Ha Yoo. Policies to Reduce Rent Seeking in Controlled Markets[J]. International Economic Journal,2007,211:.

天津市东丽区空港三号桥汇智环路 1 号武警后勤学院＼cjkstart张婧（收） 18920382303 